\title{
Trade Volume and Exchange Listing in the Market for ETFs
}

\author{
Stephen N. Jurich \\ University of Maine
}

The flow of assets into exchange traded funds (ETFs) has led to a competition among trading venues. This study analyzes the determinants of share volume and the benefits to listing ETFs. While NASDAQ captures more market share in Nasdaq-listed ETFs, the majority of share volume on the NASDAQ book is from ETFs listed on other exchanges. There is also evidence of off-exchange trading in the ETF market, as a large portion of consolidated volume is reported through the Nasdaq-FINRA Trade Reporting Facility (TRF). Together, the NASDAQ exchange and Nasdaq-TRF account for more than half of the volume in Nasdaq-listed ETFs.

Keywords: ETFs, Volume, Market Quality, Exchange Listing

\section{INTRODUCTION}

The increase in exchange traded funds (ETFs), and other exchange traded products, has created a competitive platform for market share. In terms of trading volume, NYSE Arca had the greatest market share of ETFs in 2017, (NYSE Quarterly Report, Dec. 31, 2017). But NASDAQ makes a similar claim, "As the largest ETF exchange based on volume, Nasdaq offers a trading venue with deep liquidity and transparency." (nasdaqtrader.com, New ETP Listing, March 6, 2018). Nasdaq-OMX has made multiple attempts to attract trading volume in ETFs, including an experimental phase in which the PSX was designated as an ETF exchange. The BATS exchanges have also captured market share in US ETFs. While the majority of US ETFs are listed on NYSE Arca, other exchanges also list the securities. Inevitably, the trading venues continue to adapt to the burgeoning market. Nguyen and Phengpin (2009) explain that the active market for ETFs attracts competition from exchange trading venues.

The purpose of this study is to analyze the ability of exchanges to attract volume and market share. If the market model implemented by the respective exchange improves market quality for ETFs, then informed traders will migrate towards this market. The exchange with the more favorable market structure for ETFs will have an increase in volume. What attributes allow exchanges to capture market share? This study contributes to the ongoing debate about market fragmentation and consolidation.

This study examines the benefits of listing ETFs in order to increase ETF trading volume. There is evidence that listing ETFs does not guarantee that an exchange will capture market share in the securities. To maintain a point of reference, the study focuses on the three Nasdaq-OMX exchanges to illustrate changes in the industry and the success of different market structures. In terms of trading volume, NASDAQ actually trades more non-listed ETFs than it does Nasdaq-listed ETFs. But NASDAQ enjoys the greatest market share in Nasdaq-listed ETFs. 
Trades that take place off-exchange, but are reported to the NASDAQ-FINRA trade reporting facility (TRF), make up a large portion of consolidated volume in US ETFs. (FINRA 7220A) The TRF reports the trade to the consolidate tape system (CTS). O'Hara and Ye (2011) explain that the TRF data provide an accurate measure of off-exchange stock volume. Kwan, Masulis, and McInish (2015) note that the NASDAQ-FINRA TRF and the NYSE-FINRA TRF, were the only two TRFs in 2011 which was still true at the beginning of 2018. According to the Rule 6300A Series, the NASDAQ-FINRA TRF includes trades reported to both the NASDAQ-FINRA TRF Carteret and the NASDAQ-FINRA TRF Chicago. However, the Carteret TRF and Chicago TRF are two distinct facilities. In the sample of Menkveld, Yueshen, and Zhu (2017), the NASDAQ-TRF accounts for $92 \%$ of trading volume.

\section{Where Do the ETFs Trade?}

The market for ETFs continues to change. As of December 31, 2017, there were 2,108 ETFs listed in the U.S. The average daily value of U.S. ETF transactions was $\$ 69$ billion with average daily volume of 1.2 billion shares traded. According to the 2017 NYSE exchange traded funds quarterly report, the NYSE Arca has the most market share in trading volume with twice that of the next largest exchange. (NYSE Quarterly Report, Dec. 31, 2017). Furthermore, over 80\% of Assets Under Management (AUM) of US ETFs are listed on NYSE Arca in 2017 compared to 92\% of total AUM in 2016. NYSE Arca captured $22 \%$ of exchange volume market share in 2017 . NASDAQ had $10.7 \%$ of the market share in trading volume, while BX and PSX maintained $2.9 \%$ and $1.3 \%$, respectively. BATS had $7.6 \%$ of the market share in US ETFs.

The landscape of ETFs has changed considerably since its inception. In the sample of Nguyen and Phengpin (2009) from June 2004, ETFs traded on nine exchanges. In analysis of the entry by the New York Stock Exchange (NYSE) into ETF markets via Unlisted Trading Privileges, Boehmer and Boehmer (2003) found that the NYSE captured a considerable market share of the ETFs trading volume. Nguyen, Van Ness, and Van Ness (2007) find that the large scale entry of a new exchange reduces trading costs and improves market quality for SPY, DIA, and QQQ. Nguyen, et al. (2007) explain that ETFs trade on multiple venues while noting that Reg NMS gave price priority across all markets, including that of ETFs. Nguyen et al. (2007) illustrate the market share of exchanges trading SPY, DIA, and QQQ. Their sample showed that INET (27.7\%) was the market leader followed by ArcaEx (26.15\%), Nasdaq (26.15\%), Amex (10.75\%), NYSE (4.71\%), and Regionals (13.25\%).

O'Hara and Ye (2011) show that the major US exchanges NASDAQ (31.03\%) and NYSE (21.27\%) maintain the greatest market share. However, much of the trading in equity markets occurs off-exchange. In the sample of O'Hara and Ye (2011) from the first quarter of 2008, 17.8\% of volume was reported to the NASDAQ-FINRA TRF and $6.4 \%$ of volume to the NYSE-FINRA TRF. Both NYSE and Nasdaq have been losing market share to TRF venues.

\section{Listing Exchange and Market Share}

There were 2,108 US ETFs as of December 31 ${ }^{\text {st }}, 2017$ and 1,498 ETFs listed on NYSE Arca. (NYSE Release, December 31, 2017) There were 363 ETFs listed on Nasdaq and 247 listed on BATS. But the number of NYSE Arca ETF listings had decreased from 1,510 ETF as of December $31^{\text {st }}, 2016$. The ETF market is in a constant state of flux. NYSE Arca had 113 new ETF listings in 2016. Douglas M. Yones, NYSE Head of Exchange Traded Funds explained that there were 70 new ETFs listed on NYSE Arca in 2017. According to the NYSE Quarterly report, there were 270 new product launches in 2017 . According to Nasdaqtrader.com, Nasdaq had 113 new listings in 2016 and 61 in 2017, over which time the BATS exchange had 92 new listings.

Several ETFs have changed their listing exchange over time. In August 2017, BlackRock delisted 50 of its funds from the NYSE Arca and changed their primary listing venue to the BATS (20) or Nasdaq (30) stock exchanges. (etf.com, Bell, July 3, 2017) On the other hand, one ETF transferred to NYSE Arca in the $4^{\text {th }}$ quarter of 2017. Bennett and Wei (2006) find that trading costs decline when firms move from NASDAQ to the NYSE. Some ETFs simply become inactive. There are 363 active ETFs listed on NASDAQ, but 390 total are listed as of December 31 2017. 


\section{Industry Change and Exchange Consolidation}

Changes in the ETF market have coincided with a wave of consolidation in the securities exchange industry. Much of the ETF volume occurs on exchanges that are owned by Exchange Conglomerates. These conglomerates have diversified their markets and attracted order flow. Goldstein, Shkilko, Van Ness, Van Ness (2008) suggest that the landscape of market competition for order flow has changed with consolidation and coordination with the mergers of ECNs and large trading venues. ECNs have different regulations and subsequently unique characteristics that may attract trading volume. O'Hara and Ye (2011) explain that the addition of new trading venues has increased competition, forcing traditional exchanges to lower trading charges and other fees.

The Intercontinental Exchange (ICE) is the parent company of the NYSE-Euronext Group. NYSE Arca was the result of a merger in April 2016 between Archipelago Holdings and NYSE Group. In 2008, NYSE Euronext acquired Amex. In 2007, NASDAQ acquired the Boston Stock Exchange and in 2008 the Nasdaq-OMX group acquired the Philadelphia Stock Exchange. CBOE acquired BATS in 2017 and BATS is attracting a large number of new ETF listings. CBOE began listing on the BZX Exchange in January 2012. (CBOE.com Release, ETF Market Place, January 2012).

\section{Specialized ETF Trading Venues}

As the market of ETFs has grown, several exchanges have adapted their market structure to be attractive trading venues. A wave of mergers and acquisitions in the industry allowed exchange groups to focus trading venues for ETFs. When Nasdaq-OMX, added features to PSX to facilitate the trading of exchange-traded products, particularly those with limited volume. Eric Noll, Nasdaq-OMX's executive vice president of Transaction Services, said in the press release in April, 2013, "PSX is a key piece of our larger strategy to better service the ETP industry with a platform designed to incent high-quality liquidity, market incentive programs and ETP-specific functionality." (etf.com, Ludwig April 30, 2013) NASDAQ ultimately abandoned the market model in May 2014 and made the PSX an exchange catering to larger order size.

Both the NYSE Arca and NASDAQ are offering end-to-end ETF markets which include: indexing, listing, and trading. The major exchanges also tout their liquidity and transparency. Market makers also play a role in the exchanges ability to attract volume. The market maker of the Nasdaq ETF Market is the Designated Liquidity Provider (DLP), who receives incentives to support ETFs during initial listing and to maintain market quality. The NYSE Arca ETP market quality infographic claims to, "offer a robust trading platform and enhanced market making programs that support our exchange position as the deepest source of ETF liquidity." (NYSE Release, December 31, 2017)

\section{LITERATURE REVIEW \& HYPOTHESIS DEVELOPMENT}

Theoretical predictions are mixed about the benefits of multi-venue trading. Pagano (1989) argues that orders will gravitate to the more liquid market making equilibrium trading on two markets inherently unstable. Chowdry and Nanda (1991) analyze a situation where large uninformed traders optimally split orders among market centers. The dynamic ETF market provides a natural experiment with which to test these theories. Parlour and Seppi (2003) predicts that competition between exchanges can increase or decrease the cost of liquidity.

O'Hara \& Ye (2011) find that US equity markets feature substantial fragmentation, but for Nasdaqlisted stocks more so than NYSE-listed stocks. Bennett and Wei (2006) imply that companies with more fragmented trading on Nasdaq experience larger improvements in market quality when switching to the NYSE. Bennet and Wei (2006) suggest that order flow consolidation is more valuable for less liquid securities. Boehmer and Boehmer (2003) find that entry into the NYSE improved market liquidity for the ETFs and the NYSE captured a considerable portion of the ETF trading volume.

Goldstein et al. (2008) find that the three major electronic communication networks (ECNs) such as Archipelago, Instinet, and Island offer cheaper and quicker trading than NASDAQ's SuperMontage. Goldstein et al. (2008) suggest that the ECNs have attracted a substantial amount of the trading volume of 
NASDAQ securities because they offer cheaper and quicker trading than NASDAQs SuperMontage. However, SuperMontage maintains significant market volume because it offers stability in volatile times and the ECNs are limited in the liquidity they offer traders.

The following conjecture implies that a primary listing exchange will receive the majority of its trade volume from ETFs listed on that exchange. Even if the exchange trades securities from other exchanges, it is logical to assume that an exchange with listing privileges will capture a majority of its trade volume from securities listed on that exchange.

Hypothesis 1 (Volume): An exchange will have more volume in ETFs listed on the exchange.

Hamilton (1979) presents two scenarios. The competition hypothesis suggests that the primary exchange will narrow spreads in attempt to retain trading volume. On the other hand, fragmentation coincides with lower volume on the positing market. The listing exchange will make efforts to attract volume in securities for which it is the primary market. Empirically, Boehmer and Boehmer (2003) show that when the NYSE enters into the mix, the AMEX lost considerable market share to the NYSE as did the NASDAQ and the regional exchanges for all of the ETFs. Exchanges should maintain the greatest market share for listed securities.

Hypothesis 2 (Market Share): The market share of ETF trade volume is greater for the exchange where the ETF is listed.

According to Boehmer and Boehmer (2003), ETFs have less potential than stocks for private information, but they may still represent some risk to market makers. Market rent can be a larger portion of trading costs. They conclude that broader access to the ETFs increased competition which facilitated growth and price discovery in the ETF market. Goldstein et al. (2008) explain that there are benefits for traders to route orders through the ECNs, but NASDAQ maintains characteristics that allow it to keep its substantial share of order flow volume.

O'Hara and Ye (2011) suggest that TRF fragmentation is more important for Nasdaq-listed stocks, because fragmentation affects small stocks more than it does large stocks. Kwan, Masulis, and McInish (2015) suggest that trading venues that report to the NYSE-FINRA TRF are likely to operate as dark ECNs. For stock prices above $\$ 1.00$, Kwan et al. (2015) observe a decrease in exchange volume (and market share), but an increase in dark ECN volume (and market share). Given the characteristics of ETFs listed on different exchanges, I hypothesize that the ETF trading volume reported to the NASDAQFINRA TRF is not homogenous.

Hypothesis 3 (Trading Venue): The amount of trading volume reported through the NASDAQ-FINRA $T R F$ will differ among the listing exchanges.

\section{METHODOLOGY}

\section{Data and Sample Selection}

The primary data source is Nasdaqtrader.com, which includes ETF share volume reported to the consolidated tape using NASDAQ-operated systems. In addition to NASDAQ, BX, and PSX, the data also includes ETF share volume for executed trades reported to the NASDAQ-FINRA Trade Reporting Facility (TRF). To measure fragmentation in individual stocks, O'Hara and Ye (2011) measure volume in individual stocks reported to the TRFs. O'Hara and Ye (2011) report consolidated volume by reporting venue.

The sample period begins in October 2010, and ends in October 2017. ETF specific data for Volume, Bid-Ask Spread, Price, Shares, and Returns come from the Center for Research in Security Prices (CRSP). Agrrawal, Clark, Agarwal, and Kale (2014) find that the most liquid ETFs typically have lower bid-ask spreads, higher market capitalizations, lower expense ratios, and higher average trading volumes. 


\section{Market Share}

In addition to measured average daily dollar volume and average daily share volume, several studies analyze market share (e.g. Nguyen and Phengpis, 2009). O'Hara and Ye (2011) reports, TRF\%, which is the share of consolidated volume executed in TRFs. Kwan, et al. (2015) define market share as the share volume occurring in a venue type divided by the total share volume across all venue types. The sample of US ETFs includes matched share volume of executions on the NASDAQ book expressed as a percentage of consolidated market volume. For instance, the matched market share volume of the NASDAQ book is expressed as a percentage of consolidated volume, such that market share volume ${ }_{i, t}$ for trading venue $i$ at time period $t$.

\section{RESULTS}

The descriptive statistics in Table 1 are for volume in US ETFs. Total volume reported to the consolidated tape was $23,478,402,325$ per month for the sample period. NASDAQ's monthly matched volume was 3,250,319,413, while 7,177,570,915 shares were reported to the NASDAQ-FINRA TRF. Therefore, total shares reported to Nasdaq was 10,0427,890,328. Matched volume of 632,914,063 BX and $362,807,865$ PSX exchanges were considerably less. Nevertheless, NASDAQ accounts for a large amount of volume in US ETFs (See Table 1).

Table 2 shows that NASDAQ captured $13.8 \%$ of monthly market share, but $44.5 \%$ of trades are reported to either NASDAQ or the Nasdaq-TRF. The BX and PSX exchanges maintained $2.7 \%$ and $1.5 \%$, respectively. While $45.3 \%$ of ETF volume was reported to the consolidated tape using NASDAQ operated systems, the NASDAQ does not have the greatest market share in ETFs. However, the offexchange trading venues that employ the Nasdaq-TRF appear to capture a considerable portion of share volume (Table 2).

\section{Difference Among Listing Exchange}

Table 3 illustrates the difference between Nasdaq-listed ETFs and non-listed ETFs which the data generally designates as Amex \& Regional ETFs. NASDAQ, BS, and PSX all had considerably more volume in ETFs listed on other exchanges. Monthly consolidated volume of Nasdaq listed ETFs was 1,289,120,606 compared to 22,189,281,719 for securities categorized as Amex and Regional listed (i.e. non-listed). While only 420,735,558 shares of Nasdaq-listed ETFs are reported to the Nasdaq-TRF, $6,756,835,357$ shares of Amex \& Regional ETFs are reported to the NASDAQ-FINRA TRF. Similarly, the monthly matched volume on the BX exchange was 32,751,304 while BX's matched volume for ETFs listed on other exchanges was 600,162,758. PSX also had considerably more volume in ETFs listed on other exchanges. The results suggest that Nasdaq-OMX trading venues have considerably more trading volume in ETFs that are listed on other exchanges than it does in NASDAQ-listed ETFs (See Table 3).

In Table 4, matched market share represents share volume of Nasdaq-listed US ETFs that are executed on the NASDAQ book expressed as a percentage of consolidated market volume. NASDAQ captured $20.9 \%$ of the matched market share volume in Nasdaq-listed ETFs, while only $13.4 \%$ of the nonlisted ETFs. Over 53\% of monthly share volume in Nasdaq-listed ETFs were either executed on the NASDAQ book or were reported to the Nasdaq-TRF compared to the $44.0 \%$ of non-listed ETFs. The PSX had more matched market share in Nasdaq-listed ETFs. However, there was not a major difference for BX. The results suggest that NASDAQ maintains a greater market share in Nasdaq-listed ETFs (See Table 4).

The results suggest that NASDAQ maintains a competitive advantage in attracting volume for Nasdaq-listed ETFs. Nevertheless, the vast majority of ETF volume on Nasdaq-OMX trading venues comes from ETFs that are listed on other exchanges.

\section{Market Changes}

In order to control for changes in market structure I analyze changes in the industry throughout the sample period. Consolidation allowed exchange groups to focus trading venues for ETFs. The 
development and innovation of exchange traded products led to a dynamic market. Agrrawal, Clark, Agarwal, and Kale (2014) note the transition of ETF liquidity over the 2009-2014 period indicates that there is liquidity persistence and factor strengthening across all variables. Bid-ask spreads and expense ratios have compressed, which is a good trend for investors (Agrrawal et al., 2014).

Figure 1 shows that trading volume in ETFs over the sample period. Panel A indicates that trade volume NASDAQ-listed ETFs has changed drastically over the seven-year period. It also shows that trades reported to the NASDAQ TRF have increased since 2012. Together, NASDAQ and the TRF account for a majority of the volume in NASDAQ-listed ETFs throughout the sample period. Panel B of figure 1 illustrates the dramatic decrease in NASDAQ's ability to attract volume of ETFs listed on other exchanges on NASDAQ. Alternatively, trades reported to the NASDAQ-FINRA TRF increase over the sample period. The figures illustrate where and how much ETFs trade (See Figure 1).

Figure 2 illustrates the changes in market share for NASDAQ and the NASDAQ-TRF. Panel A provides the market share of Nasdaq-listed ETFs. While NASDAQ's market share of Nasdaq-listed ETFs has decreased throughout time, the NASDAQ-TRF has captured considerable market share. Panel B shows that NASDAQs market share of Regional and Amex-listed ETFs has decreased over time. On the other hand, the market share of the NASDAQ-TRF has increased throughout the sample period (See Figure 2).

\section{Determinants of Market Share}

In order to analyze the determinants of market share, I propose the following model. Industry is a vector intended to capture different shifts in the market for ETFs. For instance, the period in which the PSX exchange was designated as NASDAQ's trading venue for ETFs in April 2013, is an important shift in the industry. The PSX was ultimately unable to capture considerable market share in ETFs and NASDAQ rebranded it in May 2014. Boehmer and Boehmer (2003) find that the AMEX lost considerable market share to the NYSE as did the NASDAQ and the regional exchanges for all of the ETFs.

Table 5 reports the results of multivariate regressions. The dependent variable is the market share of Nasdaq expressed as a percentage of total consolidated volume in US ETFs. The coefficient for Nasdaqlisted funds is significant and positive in three of the four models. The result is the strongest in the fullmodel, with the natural log of consolidated volume and year fixed-effects. There appears to be $11.9 \%$ increase in Nasdaq's market share of Nasdaq-listed securities. Nasdaq's market share also appears to increase as consolidated volume increases (See Table 5).

Table 6 reports the results of multivariate regressions with the Total Reported Market Share as the dependent variable, which includes volume of executions on NASDAQ and those reported at the NASDAQ-FINRA TRF. The coefficient of the binary variable for Nasdaq-listed securities is positive and significant in three of the four models. There is a $9.4 \%$ increase in market share of Nasdaq and the Nasdaq-FINRA TRF trades (See Table 6).

Table 7 reports the results for OLS regressions in which the market share of the NASDAQ-TRF is the dependent variable. The coefficient for Nasdaq-listed securities is positive and significant in the base models. The result suggest that the NASDAQ-TRF captures more market share in Nasdaq-listed ETFs. This result is consistent with O'Hara and Ye (2011) who find that the TRF fragmentation is more important for Nasdaq-listed stocks which are typically smaller. O'Hara and Ye (2011) suggest that the off-exchange venues that report to the TRFs provide a more competitive alternative for Nasdaq-listed stocks (Table 7).

\section{CONCLUSIONS}

This study examines the determinants of ETF trading volume in terms of market structure. The ETF market is dynamic and trading venues continue to adapt. Total share volume in US ETFs reported to the consolidated tape was 23,478,402,325 per month for the sample period of 2010 to 2017. NASDAQ and the Nasdaq-TRF accounted for 10,0427,890,328 per month in share volume of US ETFs from 2010 to 
2017. Contrary to the volume hypothesis, of the monthly share volume routed through NASDAQ and the Nasdaq-TRF, the average monthly share volume was 688,216,569 in Nasdaq-listed securities. The other 9,739,673,759 monthly shares that traded through Nasdaq were ETFs listed on other exchanges.

There is support for the market share hypothesis. NASDAQ is able to capture $20.9 \%$ of the market share in Nasdaq-listed ETFs compared to $13.4 \%$ of share volume in ETFs listed on other exchanges. However, much of the volume in ETFs is reported to the Nasdaq-TRF. For Nasdaq-listed ETFs, 32.6\% of market share volume is reported to the Nasdaq-TRF. As would be expected, the market structure of Nasdaq accounts for most of the trading in the security in Nasdaq-listed securities.

While US equity markets are spatially fragmented, according to O'Hara and Ye (2011), they are virtually consolidated. The results of this study suggest that US ETF markets are no exception. ETF volume continues to flow through a variety of trading venues. In support of the trading venue hypothesis, there is substantial evidence that much of the trading in ETFs is off-exchange. While NASDAQ captured $13.8 \%$ of market share, $30.7 \%$ of shares are reported through the NASDAQ-FINRA TRF. Thus, the offexchange venues that report through the TRFs appear to offer a competitive alternative in the market for ETFs.

Trading venues continue to adapt to the changing market for ETFs. Of the 616 ETFs on the Nasdaq Tier 1 list, there are 109 ETFs listed on Nasdaq, 467 NYSE-listed, and 39 ETFs listed on CBOE BZX. Nasdaq-OMX appears to be comfortable in its role in the ETF market. Future research could shed more light on the specific attributes of ETFs which provide the most order flow.

Exchange officials benefit from the findings as they continue to adapt. Regulators and market participants could also benefit from the study. The findings could be beneficial to fund families when choosing the primary listing exchange. While there is no certainty in the utility drawn from this paper, there is little doubt that the market for ETFs will continue to change.

TABLE 1

ETF VOLUME AND MARKET SHARE

\begin{tabular}{cccccc}
\hline & Mean & Median & Stand. Dev. & Minimum & Maximum \\
\hline $\begin{array}{c}\text { Consolidated } \\
\text { Volume }\end{array}$ & $23,478,402,325$ & $22,284,453,368$ & $5,719,697,467$ & $15,203,022,540$ & $48,757,185,420$ \\
Nasdaq Volume & $3,250,319,413$ & $2,839,942,200$ & $1,389,565,044$ & $1,850,065,899$ & $10,325,126,440$ \\
NASDAQ- & $7,177,570,915$ & $6,679,390,864$ & $1,821,413,160$ & $4,601,127,648$ & $11,922,098,095$ \\
$\begin{array}{c}\text { FINRA TRF } \\
\text { Total Shares } \\
\text { Reported }\end{array}$ & $10,427,890,328$ & $9,925,563,076$ & $2,444,428,288$ & $6,827,025,873$ & $21,224,964,556$ \\
$\begin{array}{c}\text { Handled } \\
\text { Volume }\end{array}$ & $10,615,666,238$ & $10,130,164,268$ & $2,525,610,763$ & $6,936,558,134$ & $22,096,304,107$ \\
$\begin{array}{c}\text { BX Matched } \\
\quad \text { Volume }\end{array}$ & $632,914,063$ & $617,563,130$ & $132,758,230$ & $380,565,924$ & $958,662,552$ \\
$\begin{array}{c}\text { PSX Matched } \\
\text { Volume }\end{array}$ & $362,807,865$ & $328,563,417$ & $153,411,087$ & $104,721,949$ & $964,853,009$ \\
\hline
\end{tabular}

The table reports descriptive statistics for consolidated volume, NASDAQ matched volume, BX matched volume, PSX matched volume, and trades reported to the FINRA-NASDAQ TRF. In Panel B, Matched Market Share represents share volume of US ETFs that are executed on the NASDAQ book expressed as a percentage of consolidated market volume. Handled Market Share represents ETF share volume reported to the consolidated tape using NASDAQ-operated systems. The sample period begins in October 2010 and ends in October 2017. 
TABLE 2

TRADING VENUE MARKET SHARE IN ETFS

\begin{tabular}{cccccc}
\hline & Mean & Median & Stan. Dev. & Min & Max \\
\hline NASDAQ Matched Market Share & $13.8 \%$ & $13.2 \%$ & $3.9 \%$ & $8.5 \%$ & $21.2 \%$ \\
NASDAQ-TRF Market Share & $30.7 \%$ & $31.3 \%$ & $3.9 \%$ & $22.4 \%$ & $38.3 \%$ \\
Total Reported Market Share & $44.5 \%$ & $44.6 \%$ & $1.5 \%$ & $41.7 \%$ & $48.4 \%$ \\
Handled Market Share & $45.3 \%$ & $45.3 \%$ & $1.6 \%$ & $41.2 \%$ & $49.5 \%$ \\
BX Matched Share & $2.7 \%$ & $2.8 \%$ & $0.5 \%$ & $1.8 \%$ & $3.7 \%$ \\
PSX Matched Share & $1.5 \%$ & $1.5 \%$ & $0.5 \%$ & $0.4 \%$ & $3.0 \%$ \\
\hline
\end{tabular}

Descriptive statistics for market share of ETFs by trading venue are reported. NASDAQ Matched Market Share represents share volume of US ETFs that are executed on the NASDAQ book expressed as a percentage of consolidated market volume. Total Reported Market Share represents trades reported to NASDAQ and the TRF. Handled Market Share represents ETF share volume reported to the consolidated tape using NASDAQ-operated systems. The sample period begins in October 2010 and ends in October 2017.

$$
{\text { Market Share } \text { Volume }_{i, t}}=\frac{{\text { ETF } \text { Volume }_{i, t}}_{\text {Consolidated Market Volume }}}{\text { Mard }}
$$

TABLE 3

DIFFERENCE IN NASDAQ-LISTED AND NON-LISTED ETFS

\begin{tabular}{ccccc}
\hline & Non-Listed & NASDAQ Listed & & \\
& Mean & Mean & Difference & t-stat \\
\hline Consolidated Volume & $22,189,281,719$ & $1,289,120,606$ & $20,900,161,113$ & $35.47^{* * *}$ \\
NASDAQ Matched Volume & $2,982,838,402$ & $267,481,011$ & $2,715,357,391$ & $19.11^{* * *}$ \\
NASDAQ FINRA TRF Volume & $6,756,835,357$ & $420,735,558$ & $6,336,099,799$ & $34.06^{* * *}$ \\
Total Shares Reported & $9,739,673,759$ & $688,216,569$ & $9,051,457,190$ & $36.18^{* * *}$ \\
Handled Volume & $9,915,400,673$ & $700,265,565$ & $9,215,135,108$ & $35.62^{* * *}$ \\
BX Matched Volume & $600,162,758$ & $32,751,304$ & $567,411,454$ & $41.26^{* * *}$ \\
PSX Matched Volume & $339,094,782$ & $23,713,083$ & $315,381,699$ & $19.89^{* * *}$ \\
\hline
\end{tabular}

The results for difference tests in mean monthly share volume of Nasdaq-listed ETFs relative to ETFs not listed on Nasdaq. Data consolidated volume, Nasdaq matched volume, BX matched volume, PSX matched volume, and trades reported to the FINRA-Nasdaq TRF. ***, **, or * represent statistical significance at the $1 \%, 5 \%$, or $10 \%$ level, respectively. 
TABLE 4

DIFFERENCE IN NASDAQ-LISTED ETFS AND AMEX \& REGIONAL ETFs

\begin{tabular}{ccccc}
\hline & $\begin{array}{c}\text { Non-Listed } \\
\text { Mean }\end{array}$ & NASDAQ Listed & & \\
& Mean & Difference & t-stat \\
\hline Matched Market Share & $13.4 \%$ & $20.9 \%$ & $-7.50 \%$ & $-12.39 * * *$ \\
NASDAQ-TRF Market Share & $30.6 \%$ & $32.6 \%$ & $-2.00 \%$ & $-2.54 * *$ \\
Total Reported Market Share & $44.0 \%$ & $53.4 \%$ & $-9.40 \%$ & $-23.39 * * *$ \\
Handled Market Share & $44.8 \%$ & $54.4 \%$ & $-9.60 \%$ & $-23.78 * * *$ \\
BX Matched Share & $2.8 \%$ & $2.7 \%$ & $0.10 \%$ & 0.96 \\
PSX Matched Share & $1.5 \%$ & $1.9 \%$ & $-0.40 \%$ & $-3.87 * * *$ \\
\hline
\end{tabular}

The results of difference tests in means of market share in NASDAQ-listed and ETFs not listed on NASDAQ are reported. Matched Market Share represents share volume of US ETFs that are executed on the NASDAQ book expressed as a percentage of consolidated market volume. Total Reported Market Share represents trades reported to NASDAQ and the TRF. Handled Market Share represents ETF share volume reported to the consolidated tape using NASDAQ-operated systems. The sample period begins in October 2010 and ends in October 2017. ***,**, or * represent statistical significance at the $1 \%, 5 \%$, or $10 \%$ level, respectively.

$$
\text { Market Share Volume }_{i, t}=\frac{\text { ETF Volume }_{i, t}}{\text { Consolidated Market Volume }_{t}}
$$

TABLE 5

\section{REGRESSIONS OF MARKET SHARE ON EXCHANGE LISTING}

\begin{tabular}{|c|c|c|c|c|}
\hline $\begin{array}{c}\text { D.V. }=\text { NASDAQ } \\
\text { Market Share }\end{array}$ & $\begin{array}{c}\text { (1) } \\
\text { Estimate } \\
(\text { t-stat })\end{array}$ & $\begin{array}{c}\text { (2) } \\
\text { Estimate } \\
\text { (t-stat) }\end{array}$ & $\begin{array}{c}\text { (3) } \\
\text { Estimate } \\
(\text { t-stat })\end{array}$ & $\begin{array}{c}\text { (4) } \\
\text { Estimate } \\
(t \text {-stat })\end{array}$ \\
\hline Intercept & $\begin{array}{c}0.1340 * * * \\
(31.46)\end{array}$ & $\begin{array}{c}0.4077 \\
(1.44)\end{array}$ & $\begin{array}{c}0.1827 * * * \\
(27.41)\end{array}$ & $\begin{array}{c}-0.1895 \\
(-1.29)\end{array}$ \\
\hline NASDAQ-Listed & $\begin{array}{c}0.0746^{* * *} * \\
(12.39)\end{array}$ & $\begin{array}{l}0.0417 \\
(1.21)\end{array}$ & $\begin{array}{c}0.0746 * * * \\
(30.32)\end{array}$ & $\begin{array}{c}0.1192 * * * \\
(6.73)\end{array}$ \\
\hline In(Consolidated Volume) & & $\begin{array}{l}-0.0115 \\
(-0.96)\end{array}$ & & $\begin{array}{l}0.0156^{* *} \\
\quad(2.54)\end{array}$ \\
\hline Year Fixed Effects & No & No & Yes & Yes \\
\hline No. Obs. (Months) & 170 & 170 & 170 & 170 \\
\hline$R^{2}$ & 0.4775 & 0.4804 & 0.9163 & 0.9196 \\
\hline $\operatorname{Adj} . R^{2}$ & 0.4744 & 0.4742 & 0.9122 & 0.9151 \\
\hline
\end{tabular}

The table reports the results of regression of the Nasdaq Market Share on the different exchange listings while controlling for total volume in the market. The Nasdaq Market Share represents the proportion of total consolidated share volume in ETFs that executes on the NASDAQs books. Consolidated volume represents all volume in US ETFs. The regressions of models (2) and (4) include the $\ln$ (Consolidated Volume) which is the natural $\log$ of consolidated volume represents all volume in US ETFs. Models (3) and (4) include year fixed effects. ***, **, or * represent statistical significance at the $1 \%, 5 \%$, or $10 \%$ level, respectively.

$$
\text { Market Share }=f(\text { Listing Exchange, Total Volume })
$$


TABLE 6

REGRESSIONS OF TOTAL REPORTED MARKET SHARE ON EXCHANGE LISTING

\begin{tabular}{ccccc}
\hline $\begin{array}{c}\text { D. } .=\text { Total Reported MS } \\
\text { Nasdaq \& TRF }\end{array}$ & $\begin{array}{c}(1) \\
\text { Estimate } \\
(t \text {-stat })\end{array}$ & $\begin{array}{c}\text { Estimate } \\
(t \text {-stat })\end{array}$ & $\begin{array}{c}\text { Estimate } \\
(t \text {-stat })\end{array}$ & $\begin{array}{c}\text { Estimate } \\
(t \text {-stat })\end{array}$ \\
\hline Intercept & $0.4399^{* * *}$ & $0.6607 * * *$ & $0.4212^{* * *}$ & $0.9192^{* * *}$ \\
& $(158.05)$ & $(3.57)$ & $(46.45)$ & $(4.60)$ \\
NASDAQ-Listed & $0.0944^{* * *}$ & $0.0679 * * *$ & $0.0944 * * *$ & 0.0348 \\
& $(23.99)$ & $(3.01)$ & $(28.20)$ & $(1.44)$ \\
In(Consolidated Volume) & & -0.0093 & & $-0.0209^{* *}$ \\
& & $(-1.19)$ & & $(-2.15)$ \\
& & & & \\
\hline Year Fixed Effects & No & No & Yes & Yes \\
No. Obs. (Months) & 170 & 170 & 170 & 170 \\
$R^{2}$ & 0.7741 & 0.7760 & 0.8433 & 0.8492 \\
Adj. $R^{2}$ & 0.7727 & 0.7733 & 0.8355 & 0.8407 \\
\hline
\end{tabular}

The table reports the results of regression of the Total Reported Market Share\% on the different exchange listings while controlling for total volume in the market. Total Reported Market Share\% represents the combined NASDAQ and the NASDAQ-FINRA TRF market share of volume in US ETFs. The regressions include the $\ln$ (Consolidated Volume) which is the natural log of consolidated volume represents all volume in US ETFs. Models (3) and (4) include year fixed effects. ***, **, or * represent statistical significance at the $1 \%, 5 \%$, or $10 \%$ level, respectively.

TABLE 7

REGRESSIONS OF NASDAQ-TRF MARKET SHARE ON EXCHANGE LISTING

\begin{tabular}{ccccccc}
\hline D.V. $=$ & $(1)$ & $(2)$ & $(3)$ & $(4)$ & $(5)$ & $(6)$ \\
NASDAQ TRF MS & $\begin{array}{c}\text { Estimate } \\
(t \text {-stat })\end{array}$ & $\begin{array}{c}\text { Estimate } \\
(t \text {-stat })\end{array}$ & $\begin{array}{c}\text { Estimate } \\
(t \text {-stat })\end{array}$ & $\begin{array}{c}\text { Estimate } \\
(t \text {-stat })\end{array}$ & $\begin{array}{c}\text { Estimate } \\
(t \text {-stat })\end{array}$ & $\begin{array}{c}\text { Estimate } \\
(t \text {-stat })\end{array}$ \\
\hline Intercept & $0.3059^{* * *}$ & 0.25297 & 0.23649 & $0.23848^{* * *}$ & $1.10866^{* * *}$ & $1.11904^{* * *}$ \\
& $(55.47)$ & $(0.69)$ & $(0.64)$ & $(24.43)$ & $(5.33)$ & $(5.27)$ \\
Nasdaq-Listed & $0.0198^{* *}$ & 0.02616 & 0.03312 & $0.01980^{* * *}$ & $-0.08438^{* * *}$ & $-0.08672^{* * *}$ \\
& $(2.54)$ & $(0.58)$ & $(0.71)$ & $(5.49)$ & $(-3.36)$ & $(-3.25)$ \\
In(Cons. Volume) & & 0.00222 & 0.00466 & & $-0.03644 * * *$ & $-0.03726^{* * *}$ \\
& & $(0.14)$ & $(0.29)$ & & $(-4.19)$ & $(-4.02)$ \\
Trading Days & & & -0.00197 & & & 0.000429 \\
& & & $(-0.54)$ & & & $(0.26)$ \\
\hline Year Fixed Effects & No & No & No & Yes & Yes & Yes \\
No. Obs. (Months) & 170 & 170 & 170 & 170 & 170 & 170 \\
$R^{2}$ & 0.0369 & 0.0371 & 0.0388 & 0.8028 & 0.8223 & 0.8224 \\
Adj. $R^{2}$ & 0.0312 & 0.0255 & 0.0214 & 0.793 & 0.8123 & 0.8112 \\
\hline
\end{tabular}

The table reports the results of regression of the NASDAQ-FINRA TRF Market Share $\%$ on the different exchange listings while controlling for total volume in the market. The regressions include the $\ln$ (Consolidated Volume) which is the natural log of consolidated volume represents all volume in US ETFs. Models (3) and (6) control for the number of trading days in each month. Models (4), (5) and (6) include year fixed effects. ***, **, or * represent statistical significance at the $1 \%, 5 \%$, or $10 \%$ level, respectively. 
FIGURE 1 (PANEL A)

VOLUME IN NASDAQ-LISTED ETFs

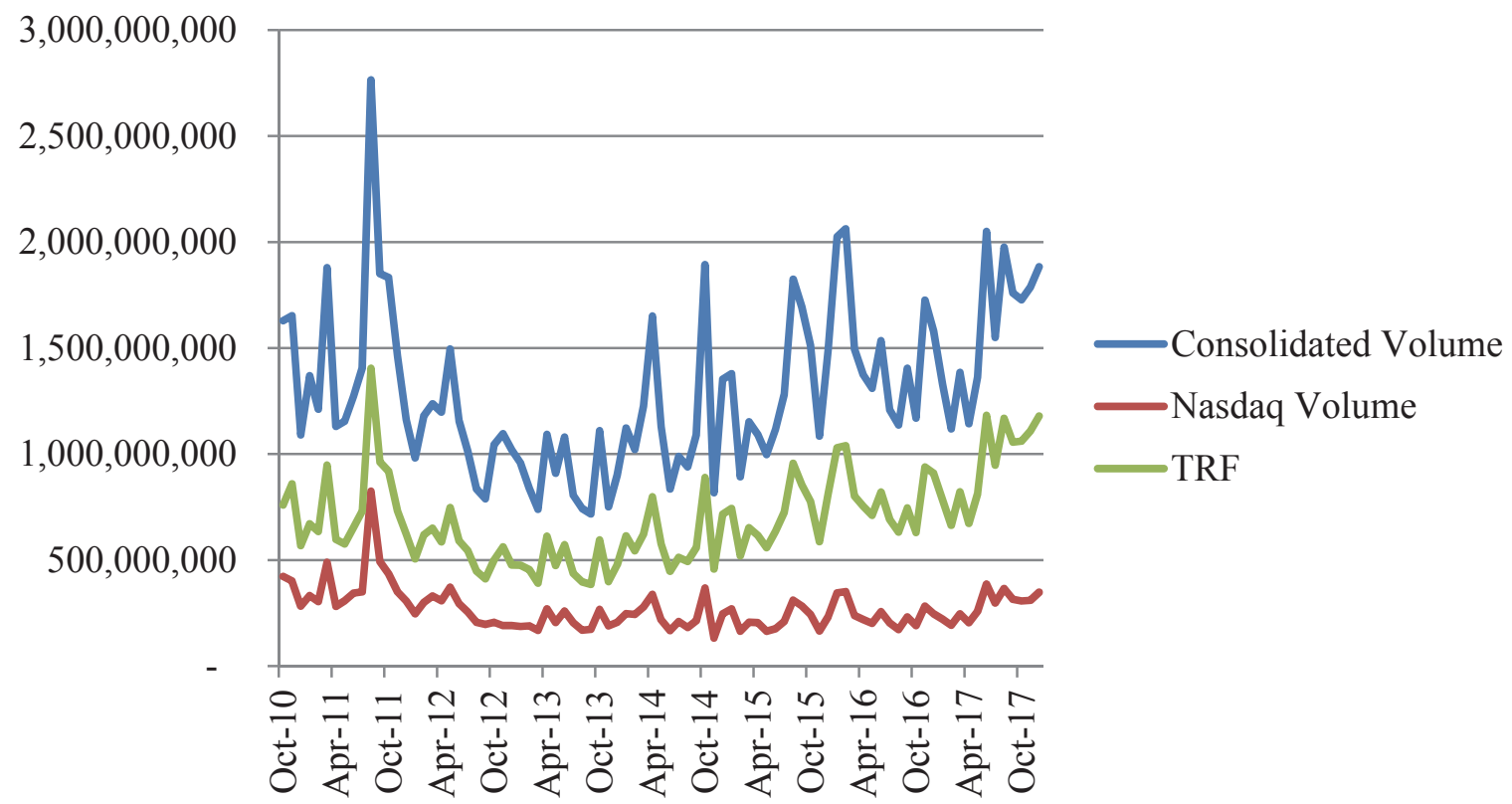

FIGURE 1 (PANEL B)

VOLUME OF AMEX \& REGIONAL ETFS

$50,000,000,000$

45,000,000,000

$40,000,000,000$

$35,000,000,000$

$30,000,000,000$

25,000,000,000

$20,000,000,000$

$15,000,000,000$

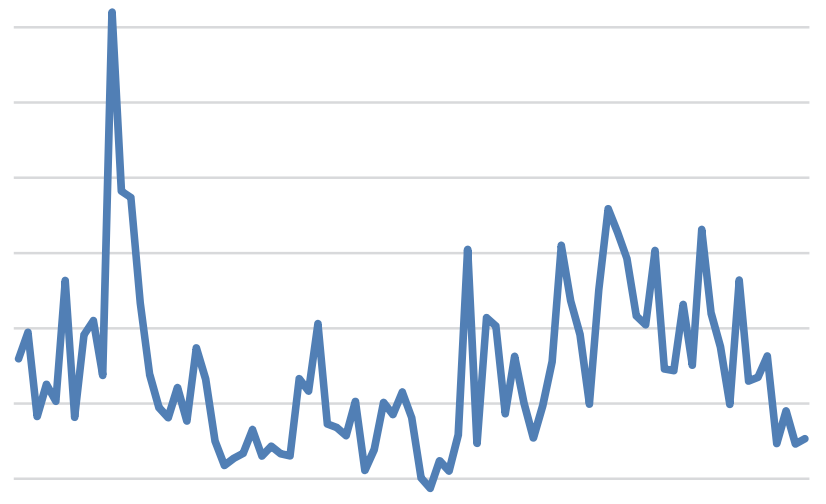

Consolidated Volume

- Nasdaq Volume

$10,000,000,000$

$5,000,000,000$

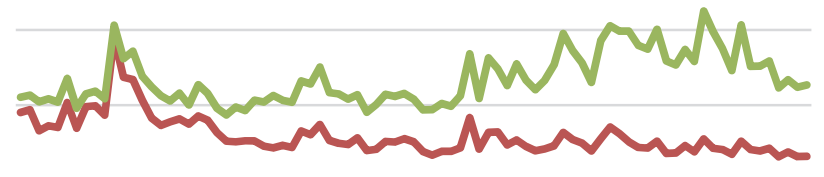

0

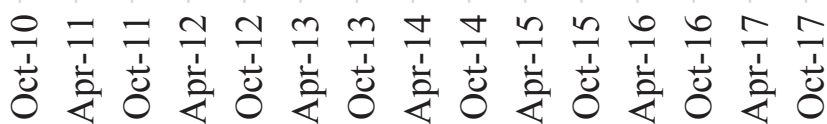


FIGURE 2

MARKET SHARE OF NASDAQ AND THE NASDAQ-TRF

Panel A: Market Share in NASDAQ-Listed ETFs

$50 \%$
$45 \%$
$40 \%$
$35 \%$
$30 \%$
$25 \%$
$20 \%$
$15 \%$
$10 \%$
$5 \%$
$0 \%$

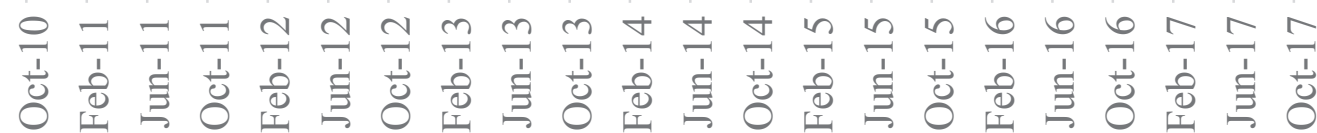

-TRF MS -NASDAQ MS

Panel B: Market Share of Regional \& Amex Listed ETFs

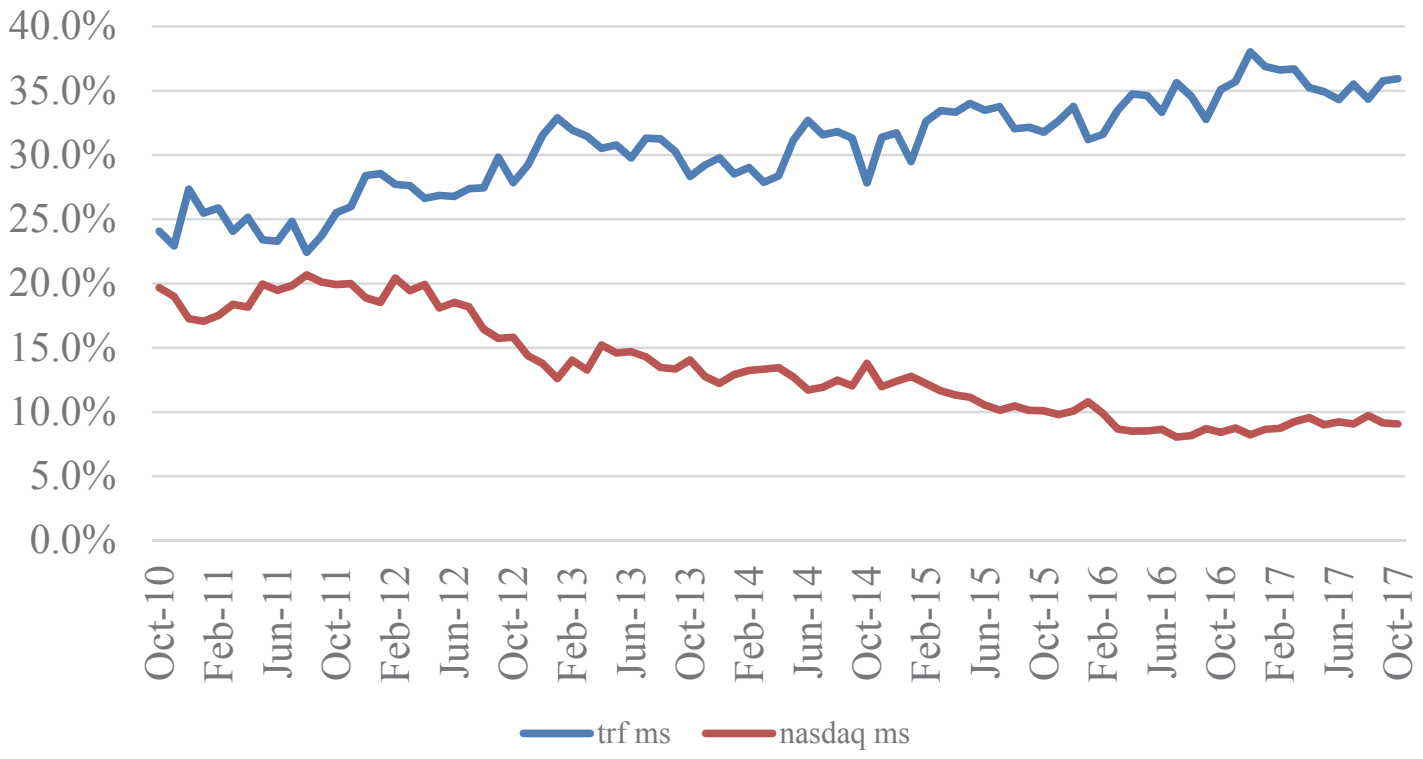




\section{REFERENCES}

Agrrawal, P., \& Clark, J.M. (2009). Determinants of ETF Liquidity in the Secondary Market: A FiveFactor Ranking Algorithm. ETF Index, 43(7), 59-66.

Agrrawal, P., Clark A., Agarwal P., \& Kale J., (2014). An Inter-temporal Study of ETF Liquidity and Underlying Factor Transition (2009-2014). Journal of Trading, 9(3), 69-78.

Bell, H., (2017). BlackRock Transfers 50 ETFs To Bats. Retrieved from http://www.etf.com/sections/features-and-news/blackrock-transfers-50-etfs-batsnasdaq?nopaging $=1$

Bennett, P., \& Wei, L. (2006). Market structure, fragmentation, and market quality. Journal of Financial Markets, 9, 49-78.

Bessembinder, H. (2003). Quote-based competition and trade execution costs in NYSE-listed stocks. Journal of Financial Economics, 70(3), 385-422.

Boehmer, E., \& Boehmer, B. (2003). Trading our Neighbor's ETF: Competition or fragmentation? Journal of Banking and Finance, 27, 1667-1703.

CBOE (2018, June 29). ETP Listings. Cboe. Retrieved from https://markets.cboe.com/us/equities/etfmarketplace/listed_products/

Chowdhry, B., Nanda, V., (1991). Multimarket trading and market liquidity, Review of Financial Studies, 4, 483-511.

Financial Industry Regulatory Authority. (2018). 7220A, Trade Reporting Participation Requirements. FINRA Manual. Retrieved from http://finra.complinet.com/en/display/display_main.html?rbid=2403\&element_id=4391 Financial

Goldstein, M.A., Shkilko, A.V., Van Ness, B.F., \& Van Ness, R.A. (2008). Competition in the Market for NASDAQ Securities. Journal of Financial Markets, 11, 113-143.

Hamilton, J.A. (1979). Marketplace Fragmentation, Competition, and the Efficiency of the Stock Exchange. Journal of Finance, 34(1), 171-187.

Industry Regulatory Authority. (2019). Overview. Trade Reporting Facility® (TRF®). Retrieved from http://www.finra.org/industry/trf

Kwan, A., Masulis, R., \& McInish, T. H. (2015). Trading rules, competition for order flow and market fragmentation. Journal of Financial Economics, 115(2), 330-348.

Ludwig, O. (2013, April 30). Nasdaq Adds ETP-Friendly Features To PSX. Retrieved from http://www.etf.com/sections/features/16657-nasdaq-adds-etp-friendly-features-topsx.html?nopaging $=1$

Madhaven, A. (1995). Consolidation, fragmentation and the disclosure of trading information. Review of Financial Studies, 8(3), 579-603.

Menkveld, A.J., Yueshen, B.Z., \& Zhu, H. (2017). Shades of darkness: A pecking order of trading venues, Journal of Financial Economics, 124(3) 503-534.

Nasdaq Corporate News Release. (2018, March 6). New ETP Listings, Nasdaq Listing. Retrieved from http://www.nasdaqtrader.com/trader.aspx?id=ETF

Nasdaq Corporate News Release. (2018, March 6). New ETP Listings, Market Listing. Retrieved from http://www.nasdaqtrader.com/Trader.aspx?id=ETF_US

NASDAQ. (2017). ETF Market Share Stats [Data Set]. Retrieved from https://www.nasdaqtrader.com/trader.aspx?id=marketshare

Nguyen, V., \& Phengpis, C. (2009). An analysis of the opening mechanisms of Exchange Trade Fund markets, The Quarterly Review Economics \& Finance, 49, 562-577.

Nguyen, V., Van Ness, B.F., \& Van Ness, R.A. (2007). Short- and Long-Term Effects of Multimarket Trading, Financial Review, 42, 349-372.

NYSE Release. (2017). Q4 2017 Report. NYSE Arca ETF Report. U.S. Market Statistics as of December 31st, 2017. Retrieved from https://www.nyse.com/etf/exchange-traded-funds-quarterly-report 
NYSE Release. (2018). Exchange Traded Funds. NYSE Arca ETP Market Quality infographic. Retrieved from https:/www.nyse.com/publicdocs/nyse/markets/nysearca/NYSE_Arca_ETP_Market_Quality_infographic.pdf

O'Hara, M., \& Ye, M. (2011). Is market fragmentation harming market quality? Journal of Financial Economics, 100(3), 459-474.

Pagano, M. (1989). Trading volume and asset liquidity. The Quarterly Journal of Economics, 104(2), 255-274.

Parlour, C.A., \& Seppi, D.J. (2003). Liquidity-Based Competition for Order Flow, Review of Financial Studies, 16, 301-343. 